\title{
PEACE AND WAR ASSOCIATIONS OF UKRAINIAN HUMANITIES STUDENTS
}

\author{
Yevheniia Vasianovych \\ Lecturer, PhD Student, V. N. Karazin Kharkiv National University, Ukraine \\ e-mail: vasianovych@karazin.ua,orcid.org/0000-0001-9696-3335
}

\section{Summary}

The aim of this paper is to analyze the associations of Ukrainian humanities students given on PEACE and WAR stimuli. The association remains an important subject for studying in many scientific fields because associating is a continued process of making links between phenomena of cultural, social and physical surroundings, consequently it can reveal some concealed procedures of thinking. Through the semantic analysis of association units, it is possible to explicit, though partially, some conceptual filling of consciousness. The associative experiment is one of the most widespread methods for obtaining empirical data for the linguistic science of our country. This paper discusses all stages of the development of such an experiment and its possible disadvantages. However, such surveys allow amendments as any experimental method, its benefits make it generally accepted in the scientific society. The stimuli were chosen due to their crucial role in current life of the Ukrainian nation. Methods used in the study: an associative experiment, semantic and quantitative analyses of the results.

Keywords: concept, associative experiment, linguistic consciousness, word-stimulus, reaction.

DOI: https://doi.org/10.23856/3855

\section{Introduction}

Nowadays studying of language as a pure static phenomenon is out of date. Connections, interactions and mixing of different disciplines cause challenging questions for modern science. It is impossible to draw a line between language and mind, language and culture, language and its psychological aspects, language and society. Human mind is a close system and one cannot observe its processes directly. Hence linguistics has to neglect the main methods of studying such as observation and introspection and to apply experimental techniques. An associative experiment is widely used for revealing peculiarities of associative thinking. The aim of the research is to represent the associate component of the concepts PEACE and WAR in Ukrainian humanities students' consciousness. Current social and political situation in Ukraine makes these stimuli crucially important for each representative of the nation.

\section{Associations and development of an associative experiment}

Linguists apply to studying the connection a person - language - society -culture. A person can be considered as a native speaker or a culture bearer. However, an important question concerns eliciting of linguistic consciousness of a person, though hidden from the direct observation. Thus, it is efficient to use experimental methods to reveal these interactions of linguistic, sociopsychological and cultural phenomena. The application of the associative experiment is reasonable enough for these aims. Through such an experiment the entire previous verbal and nonverbal experience of native speakers can be revealed. "The structure of an associative verbal 
network objectively belongs ... to the culture as a system of consciousness because the world is represented to each person through a system of meanings which determines the perception of the real world" (Ufimtseva, 2014).

The word association has its own methodological qualities: the task is generally very easy to administrate (Thwaites, 2018: 16). The usage of a written form provides the researcher with information about thoughts, ideas, feelings, attitudes and motives of people's activities and behavior through its availability and universality (Suimenko, n.d.). The word association experiment meets the requirements of empirical study. "The task continues to yield valuable insights, even as its fundamental nature is disputed" (Thwaites, 2018: 17).

Association is a dynamic temporal nerve connection between two or more mental phenomena (feelings, ideas, emotions, thoughts, images, etc.), as well as their designations in language that is formed under certain conditions on the basis of subjective response to the stimuli (Selivanova, 2010: 44).

While developing an associative experiment in psycholinguistics researchers should follow some particular stages: define research aims; identify the population and the sample; decide how to collect the replies; design a questionnaire; run a pilot survey; carry out the main experiment; analyze the data (Burgess, 2001; Suimenko, n.d.).

To define research aims is a crucially important step many scientists pay little attention to (Panina, 2001). For any empirical study it is necessary to outline the subject and for what reason it should be examined (Panina, 2001). The exact formulation of problem matter is rather a difficult creative task which is challenging for a scholar. However, it should be executive in the first place otherwise the research has no grounds to use it as basis. The questionnaire design must be sufficient enough for the needs of the research because wrong questions may lead to the inadequate data and inadequate inferences from the data. All theoretical base and the focus, analysis methods of the study are to be known before data collection (Burgess, 2001).

The second stage focuses on population, all the members of the group the researcher intends to study (Burgess, 2001). It is quite effortful and sometimes impossible to examine the whole population, so it is necessary to pick out a sample, a sub-set.

During the third stage the question arises whether the survey is to be completed by the recipient directly or through an interviewer (Burgess, 2001). A questionnaire experiment or self-administrated survey is characterized by the absence of direct contact between a correspondent and a respondent. While applying such a method researchers can receive some data only from verbal behavior of a person (Suimenko, n.d.).

According to many scientific works on questionnaire developing (Suimenko, n.d.; Burgess, 2001; Panina, 2001) it is specified by a particular structure. The lay out consists of a title, brief introductory statement, the main part and a socio-demographic passport (Suimenko, n.d.). In the latter some information (age, gender, profession etc.) is given that can be used as an additional criterion for the research. In a self-administered survey introductory statement is to be put before the main questions. It includes general instructions with the requirements on how to fill in the questionnaire, the necessity of reacting to all the stimuli given below (Panina, 2001). The way of representation of the questionnaire is very important for recipient to treat it positively: quality of paper, font, structure, design matter for the recipients' perception (Suimenko, n.d.; Burgess, 2001; Panina, 2001). "Polographic, technical and esthetic design of the questionnaire increases the interest, responsibility and quality of work for interviewers and respondents" (Panina, 2001). A small font can make the questionnaire look shorter and otherwise inconvenient for reading. Usage of italics and bold types, underlining, spaces, structured passages suit a researcher well to make an impact on respondents (Burgess, 2001). 
For appropriate results questionnaire design should consists of two steps. "The first step is to construct a questionnaire on the base of available knowledge about the subject of studying that is connected with the current state of the problem" (Suimenko, n.d.). On the second step mistakes of the questionnaire are to be corrected and amendments are to be made after the pilot survey completion (Suimenko, n.d.; Burgess, 2001). It helps to "maximize response rate and minimize error rate on answers").

Developing methodological issues concerning questionnaire surveys, it is essential to pay special attention on avoiding amendments that can arise during conducting the experiment. Y. Suyimenko points out three main reasons of the disadvantages of this method: ontological reason, psychological reason and technical reason.

In technical terms, the questionnaire can contain mistakes, misprints, excess questions or instructions, wrong structure or other faults that produces erroneous or inadequate reactions of recipients (Suimenko, n.d.).

Problems concerning psychological aspects vary immensely due to recipients. They can be caused by environmental factors such as weather, conditions, time, by the recipient's mood, their perception of the world, attitude towards the interview etc. (Krosnick \& Presser, 2009). Great amount of different psychological criteria cannot be taken into account and solved owing to its elemental nature or individual characteristics. In general respondents have no intention to lie while filling the questionnaire, however, social biases may lead to misreporting." On questions about socially desirable (or undesirable) matters, however, there are grounds for expecting such misreporting" (Krosnick \& Presser, 2009: 37). If the questionnaire refers to social, political, cultural, religious items that tend to be interpreted in a certain way from the view point of the group the recipient belongs to, responses may have nothing in common with internal physiological patterns of the recipient but reveal only traditional or established believes or ideas of their group. Representing of such bias may be conscious and intentional to seem up-to-date and aware person or even unconscious. To avoid false reactions and reduce social desirability response bias it is suggested to eliminate the interviewer or least their awareness of the respondent's answer (Krosnick \& Presser, 2009: 39). This point may be achieved by offering anonymity on self-administered questionnaires.

Due to ontological reasons misreporting may occur. The real behavior of people never completely coincides with their comprehension of it (Suimenko, n.d.). So the responses may illuminate no objective reality owing to people's inability to be aware of their true nature and realize themselves in exact way.

While developing an associative experiment in psycholinguistics researchers should follow some particular stages: define research aims; identify the population and the sample; decide how to collect the replies; design a questionnaire; run a pilot survey; carry out the main experiment; analyze the data (Suimenko, n.d.; Burgess, 2001).

\section{The experiment with Ukrainian humanities students}

For studying the place of such lexical units as PEACE and WAR in the linguistic consciousness of Ukrainian humanities students psycholinguistic associate experiment was held. For the sample students of the philology school of V. N. Karazin Kharkiv National University were chosen. Freshmen, sophomores, third-year and fourth-year students were involved in the research. The whole number of the recipients is a hundred. They were invited to fill the questionnaire with their responses. To reduce the impact of the examiner the questionnaire was designed as self-administered and anonymous. It has conventional structure, which contains 
a title, an address, an introductory statement, the main part and the words of gratitude on the bottom of the page. In the introductory statement the students were asked to write down several associations on two stimuli "Peace" and "War" in the order of their occurrence. They were also encouraged to take down reaction on the two stimuli in order the researcher might elicit the very essence of these notions. Different font type and size were used to make the questionnaire more convenient for perception; e.g. as for the stimuli, they were bigger than the other parts of the questionnaire to underline their importance and the word "several" is printed in bold for emphasizing the necessity of responding by more than one word. All the parts of the questionnaire are logically separated from each other. Owing to the results of this survey a disadvantage of the questionnaire was revealed. Due to the bilingual characteristic of the Ukrainian students, they speak both Ukrainian and Russian, some students used the Russian language in their associations written down. On account of the specialization of the study such results exposed the necessity of adding a statement of using only Ukrainian while responding to the stimuli.

On carrying out the main experiment 1086 associations were given, stimuli "Peace" and "War" obtained 530 and 556 reactions, respectively. The number of responses on both stimuli is close to equality that proves the fact of their similar importance for the recipients. The fact of occupying the significant place in their linguistic picture of the world is shown by absence of refusing to react which means that both stimuli stir up associating process in recipients' minds. More responses were represented by a single word rather than by phrases or combinations of words.

\section{PEACE stimulus}

This stimulus received 530 reactions which contains 184 different associations. 482 responses were given by a single word (cмix - laugh; допомога - help; ілюзія - illusion; надія - hоре; сдність - unity) and 48 of them contain more than one word, among them word-combinations (ясне небо - clear sky; щзасливі люди - hapру реорle; повітряні кулькиballoons; яскраві кольори - bright colors), descriptive sentences (коли немає певних суперечок між людьми - when there is nо arguing between people) or part of nominal compound sentence (любов до всього, щчо тебе оточує - love to everything that surrounds you) were met.

To determine the response probability of the reactions the strength of association measured by counting the number of people who produce each response is then divided by the sample size (Nelson, McEvoy \& Dennis, 2012). Associations спокій (calmness), щзастя (happiness), любов (love) and padicmь (joy) have the highest value of response probability: 0,48; 0,$38 ; 0,25$ and 0,25 respectively. The other reactions' values were lower than 0,16 and 154 reactions obtain 0,1 value of response probability.

On analyzing the semantic component of the associations, the following findings can be made: there are two main tendencies of reactions on stimulus PEACE. Most responses concern feelings or visualization of peaceful time (любов - love; безтурботність - carelessness; натхнення - inspiration; посмішки - smiles; радість життя - joy of life; свято - holiday; люди навколо - реорle around; гарна погода - good weather).

More than a half of the whole number of the recipients gave reactions associating with calmness. The most frequent association in this group спокій (calmness), which has the biggest value of response probability, became the most frequent association for the whole sample. Other reactions with lexeme спокій were also produced: спокій на душі-inпеr реасе; суспільний та душевний спокій - social and mental calmness. Such way of associating stimulus PEACE can be connected with word WAR with opposite meaning that can bring worry and anxiety 
because semantic meaning of such notions as peace, calmness etc. is difficult to understand without references to their antonyms (Bilodid, n.d.). Another group of reactions which can be produced only on condition that their opposites (e.g. attacks, danger etc.) exist in the linguistic picture of the world of the recipients involves such response as захист (defense), безпека (safety), захищеність (security) etc.

The second biggest group of feeling/emotions associations consists of reactions that stand for happiness and joy. It involves lexeme щастя (happiness) with high response probability and others (весела пісня - funny song; посмішки на щзасливих обличчях - smiles оп hapрy faces; щзасливі люди - hарру реорle; щасливе майбутнє - happy future).

Among researchers the links between notions and colors are promising for studying: some notions may associate with a certain color in human mind, and vice versa, a color can produce a certain notion as an association (Savchuk \& Halunova, 2019). The stimulus received no definite color word response but different ones, this fact proves that color reacting is an individual process without common or established characteristics. The recipients connect PEACE with white, blue, green and red colors (білий колір - white color, блакить - аzиге, голубий - blие, зелений - greеn, зелена трава - green grass, червоний - red) and with colorfulness (барвиcolors, яскраві кольори - bright colors).

Nowadays media tends to use different pictures and images while talking about current Ukraine situation. The main image that concerns prolonged war or the advent of peace is a child. Happy children with smiles on their faces became the embodiment of cessation of hostilities. Besides the fact that the recipients are representative of independent Ukraine, remains of old culture and layer of modern traditions and views still have mixing impact on their ideas and opinions. This fact can explain occurrence of associations concerned with children (dimuchildren; дитячий сміх - children's laugh; посмішка дитини - а child's smile; посмішка на обличчі дитини - a smile on a child's face), though students are mostly childless representatives of society.

The recipients emphasize that PEACE is just an object and there should be two or more subjects are not at enmity. It is shown by reactions співпраия (collaboration), взаєморозуміння (common understanding), потискання рук (handshaking).

The metaphor image associating with PEACE is the sky. There is a common tradition in Ukraine to wish a peaceful sky above that can produce associations connected with the sky, the sun and clouds (небо - the sky; соние - the sun; ясне небо - clear sky; білі хмарки-white clods; блакитне небо - blue sky; сонячне світло - sunshine; хмари - clouds). Some reactions are references to established signs or attributes of peace such as (голуба; голуб; трубка). Another metaphor linked with PEACE is flowers or blossom (квіти - flowers; поле квітів - a field of flowers; цвітіння - blossom; розквіт - flourishing). It can be explained by comparison that PEACE prevails after WAR like spring with its blossom after winter.

\section{WAR stimulus}

556 responses were given on this stimulus, among them 218 different reactions were represented. The recipients wrote 531 reactions as a single word and 21 associations consist more than one word (such as: політичне становище - political situation, точка неповоротностіthe point of no return, відсутність щзастя - absence of happiness; descriptive sentences: коли виникають певні конфлікти - when certain conflicts oсcur).

The most frequent associations with the highest values of response probability are cмерть (death) with 0,48, сльози (tears) with 0,31, біль (pain) with 0,29 and кров (blood) with 0,25. 
An inextricable link between WAR and death is represented by more than half of the whole number of recipients (смерть - death; могили - graves; трупи - corpses). The students associate this stimulus not only with death as a phenomenon but also with its consequences (загиблі-the deceased; жертви - victims; кістки-bones, мертві-dead pеорle). The image of dead or suffering people produces reactions connected with blood (кров - blood; багато крові - a lot of blood; кроваві жертви - blood sacrifices).

Given reactions prove the fact that certain consequences of WAR are obvious for the respondents, and the main their manifestation is destruction of the environment, the country, the nation in general and mundane routine and people's lives in particular (розруха - devastation; руїни - ruins; вбивство - а тиrder; зникнення нації-nation extinction, занепад державиstate decline; винищення- - extermination; зруйновані дома - destroyed houses; зруйновані ciм $\dddot{\imath}$ - ruined families).

The semantic meaning, which is recorded in the dictionary (Bilodid, n.d.) is connected with a lot of given associations. WAR is considered a conflict that can take different forms or scales (сварка - arguing; бійка - scuffle; бій - fight; баталії- battle; конфлікт - conflict). Some reactions present the stimulus as an armed fighting (зброя - arms; бомба - а bотb; танки - tanks; гармати - cannons; боєприпаси - ammunition; вистріли - shots) associated with military activities (військові дї- military actions; військові - the military; солдат a soldier; форма - a uniform).

Some references to war elicit from the respondents' memory particular events and their participants thereby producing reactions with proper names (Донбас - Donbas; Україна Ukraine; Росія - Russia; Aмерика - America; Ipaн - Iran; CCCP - the USSR). Taking into account the fact that the recipients are citizens of Ukraine such responses Донбас (Donbas); Україна (Ukraine) and Росія (Russia) are not of singular occurrence.

Great amount of reactions show feelings and emotions which the stimulus arouses in people's mind (страждання - suffering; агресія - aggression; ворожість - hostility; жах terror; жаль-coтраssion; смуток-sadness; втома-fatiguе; злість-anger; скорботаsorrow). It is important to point out that no responses with positive or even neutral connotation concerning feelings were given.

The metaphor representation of WAR has the similar images as PEACE - the sky and children but with antipodal characteristics. To oppose the clear sky associations with dark sky were given (темне небо - dark sky; black sky - чорне небо; сіре небо - grey sky). Children are depicted as the most vulnerable sector of population (діти - children; діти без батьків children without parents; діти, що плачуть - crying children; сироти - orphans).

The stimulus stirs up associations that concerns colors. They are black and grey (чорний - black; чорне небо - black sky; cipicmь - grey color), which can refer to negative emotions (terror or sadness) or to environmental changes (dirt, dust, destroyed buildings), and red (червоний) which is obviously associated with blood.

\section{Conclusions}

Thus, stimuli PEACE and WAR occupy a significant place in the linguistic consciousness of Ukrainian humanities students. The associations show that these two phenomena are linked inextricably in their minds and can exist only opposing each other. The number of reactions with values of response probability that are higher than 0,1 represent that students have similar ideas and views towards WAR and PEACE. This fact demonstrates that cultural, social and political events have a great impact on forming of linguistic consciousness in the minds of 
nowadays youths. On analyzing the semantic component of given responses, we can make a conclusion that the absence of reactions concerned with objects or personal events of mundane life proves that the students percept PEACE and WAR not through their own experiences but through the experience of their nation and their country. Considering current social and political situation in Ukraine, the research of peace and war concepts is promising enough.

\section{References}

Bilodid, I. (n.d.). Myr (Peace). In Slovnyk ukrainskoi movy: v 11 tomakh [The Ukrainian language dictionary in 11 volumes], volume 4. [in Ukrainian]

Bilodid, I. (n.d.). Viina (War). In Slovnyk ukrainskoi movy: v 11 tomakh [The Ukrainian language dictionary in 11 volumes], volume 1. [in Ukrainian]

Burgess, T. (2001) Information Systems Services. Guide to the Design of Questionnaires. A general introduction to the design of questionnaires for survey research. University of Leeds.

Krosnick, J. A. and Presser, S. (2009) Question and Questionnaire Design. Handbook of Survey Research (2nd Edition). James D. Wright and Peter V. Marsden (Eds). San Diego, CA: Elsevier. Nelson, D., McEvoy, C., \& Dennis, S. (2012). What is and what does free association measure? Memory \& Cognition. doi: 10.3758/BF03209337

Panina, N. (2001). Tehnologiya sociologicheskogo issledovaniya [Technology of social study]. Kyiv: In-t sociolohii NAN Ukrainy. [in Russian]

Savchuk, E., Halunova, N. (2018). Osoblyvosti spryiniattia koloropoznachen u movnii kartyni svitu anhlomovnykh predstavnykiv serednoho viku [The Specifics of the Perception of the Names of Colours in the Language World Model of English-speaking Middle-aged Representatives]. Visnyk Kharkivskoho natsionalnoho universytetu imeni V. N. Karazina. Seriia : Filolohiia, 78, 185-188. Kharkiv. Retrieved June 26, 2020, from http://nbuv.gov.ual UJRN/VKhIFL_2018_78_39

Selivanova, O. (2010). Linhvistychna entsyklopediia [Linguistic encyclopedia]. Poltava : Dovkillia-K. [in Ukranian]

Suimenko, Y. (n.d.). Anketne opytuvannia: mystetstvo stavyty zapytannia [ A questionnaire based survey: the art of asking questions]. Retrieved June 26, 2020, from https://divovo.in.ua/ anketne-opituvannya-mistectvo-staviti-zapitannya.html [in Ukrainian]

Thwaites, P.A. (2018). Lexical and distributional influences on word association response generation. Retrieved June 26, 2020, from https://www.semanticscholar.org/paper/Lexical-and-distributional-influences-on-word-Thwaites/9ceeb38ffa2edd24c57f42f6b157bca86fc3eecf

Ufimtseva, N. (2014). The Associative Dictionary as a Model of the Linguistic Picture of the World. Procedia. Social and Behavioral Sciences, 154, 36-44. 